\section{Sukupolven vaihtuminen maatilataloudessa}

Maat. ja metsät. lis. JARL LINDGREN

Väestöpoliittinen Tutkimuslaitos

Maatalous on kehittyneissä maissa läpikäynyt uudistuksen, jonka taloudelliset ja sosiaaliset vaikutukset ovat olleet syvälle käyviä. Muutosprosessi jatkuu ja on edelleen ripeä niissä maissa, joissa teollistuminen ja kaupungistuminen on päässyt myöhemmin vauhtiin. Menetelmät samoin kuin asenteet, arvot ja päämäärät ovat vaihtuneet.

Kiinnostus muuttuvan maaseutuyhteiskunnan ja siihen liittyvien ilmiöiden tutkimiseen näyttää kasvaneen varsinkin viime vuosikymmenien aikana teollistuneissa maissa. Maatilatalouden eräs vaihe, joka on joutunut tutkimuksen kohteeksi, on maatilan siirtyminen sukupolvelta toiselle. Tähän kohdistuva mielenkiinto pohjautuu ehkä pääasiassa käytännöllisiin ja maatalouspoliittisiin näkökohtiin. Sukupolven vaihtumiseen kytkeytyvät toimenpiteet ovat määrääviä maatilan tulevaisuudelle niissä maissa, missä maatalous on perheviljelmävaltaista kuten esim. Pohjoismaissa. Oikeaan aikaan ja oikealla tavalla tapahtuva maatilan siirtäminen edistää maataloudesta elävän väestön toimeentulomahdollisuuksia, mikä puolestaan on kansalaisten elintason kohoamista tavoittelevan yhteiskunnan intressinä.

Sukupolven vaihtumiseen kytkeytyvistä ongelmista, joihin erityisesti on kiinnitetty huomiota, mainittakoon maatalouden sukottuminen* ja maatilan siirtymisen vaikutus tilan rakenteeseen. Eliniän jatkuva pidentyminen on nimittäin aiheuttanut sen, että nuori sukupolvi saa tilan haltuunsa myöhemmin kuin ennen. Tämä voi vaikuttaa epäsuotuisasti maatalouden kehitykseen, koska vanhan viljelijän on todettu ottavan hitaammin käytäntöön uusia menetelmiä kuin nuoremman.

Muutokset maatilan rakenteessa tapahtuvat usein sukupolven vaihtumisen yhteydessä. Jos tila jaetaan perillisten kesken perus- ja käyttöpääoma voi jäädä vajaakäyttöiseksi, pellot pirstoutua jne. Reaalipääomaa tuhlataan ja kannattamattomia maatiloja syntyy. Jos taas tilalle jääneen viljelijän täytyy lunastaa kanssaperijänsä osuudet, seurauksena voi olla taloudellinen rasitus, joka varsinkin nykyaikana jolloin maatilan rationalisointi merkitsee työpanoksen korvaamista pääomalla voi jarruttaa maatalousyrityksen suotuisaa kehitystä, jopa vaarantaa sen elinkelpoisuutta.

Sukupolven vaihtumista valottavissa tutkimuksissa pyritään selvittämään maatilan siirtymistapoja, -muotoja ja siihen liittyviä moninaisia ongelmia. Niissä kuvataan usein suhteellisen yksinkertaisilla tilastollisilla tunnusluvuilla siirtymisen rakennetta ja sen muotoja. Myös sosiaaliantropologiset ja sosiaalimaantieteelliset tutkimukset, joissa tutkitaan maatalousyhteiskunnan rakennetta, käyttäytymistapoja ym. valottavat maatilan siirtymiseen liittyviä ongelmia. Viimeksimainituissa sukupolven vaihtuminen muodostaa ainoastaan erään tutkimuskohteen monien joukosta, ja sitä käsitellään pääasiassa sosiologisena ilmiönä.

Tutkimukset

Maatilan siirtymismuotojen tutkimuksella on vanhoja perinteitä Saksassa. Siellä on paljon aikaisempien sukupolvien vaih- 
tumista kuvaavia selvityksiä (SeringDietze, Goltz v.d., Miaskowski, ym.). Uudelleen heräsi mielenkiinto näihin ongelmiin viime maailmansodan jälkeen. Tähän lienee pohjimmiltaan syynä perinnönjakolainsäädännön muutoksen tarve (Röhm 1957). Tutkimuksen kohteena on ollut erityisesti Etelä-Saksa (Binder 1953, Dierks 1954, Röhm 1957 ja 1958, Reichle 1954, Trotha 1958 ym.). Yleensä nämä tutkimukset käsittelevät määrättyjä rajoitettuja alueita, kuten kihlakuntia, mutta myös suurempia alueita. Useat tutkimuksista ovat väitöskirjoja. Tiedot perustuvat yleensä arkistotietoihin, esim. kihlakunnan oikeuksissa säilytettyihin tilan siirtymistä koskeviin asiakirjoihin, mutta myös viranomaisille tehtyihin kirjetiedusteluihin, harvemmin haastatteluihin. Tutkimukset ovat pääasiassa deskriptiivisiä. Niissä kuvataan absoluuttisten ja suhdelukujen avulla siirtymisen kvantitatiivisesti ilmaistavissa olevia ominaisuuksia, kuten siirtymismuotoja ja ikäjakautumia ym. Eräissä tutkimuksissa (esim. Röhm 1957 ja Trotha 1958) on haluttu selvittää perimysmuotojen yleisyyttä ja syitä niihin — ts. siirtyykö tila kokonaisuudessaan yhdelle perijälle (Anerbensitte) vai jaetaanko se tavalla tai toisella perijöiden kesken (Realteilung).

Samantapaisia tutkimuksia on suoritettu Hollannissa (esim. Post-Jacobs 1963), Norjassa (Hornslien 1957) ja Yhdysvalloissa (O'Byrne-Timmons 1959, ParsonsWaples 1945 ym.). Näille tutkimuksille on tavallaan yhteistä se, että tiedot on kerätty suoraan tilanomistajilta. Näistä on Postin ja Jacobsin tutkimus Etelä-Hollannista melko perinpohjainen. Siirtymistapahtumaa selvitetään monelta näkökannalta. Norjalaisen tutkimuksen pääpaino on ihmisissä, jotka ottavat osaa siirtymistapahtumaan. Amerikkalaiset tutkimukset näyttävät usein pyrkivän korostamaan tietojen yleistä käyttökelpoisuutta ohjeina ja esimerkkeinä muille maanviljelijöille. Suomessa on tiettävästi tehty ainoastaan yksi tutkimus nimenomaan sukupolven vaihtumisesta (Pipping 1961). Tutkimus on Länsi-Suomen rannikolla sijaitsevasta Västanfjärdin pitäjästä, ja tie- dot on saatu suoraan tilanomistajilta kirjekyselyinä.

Mitä taas niihin selvityksiin tulee, joissa pääasiassa tutkitaan maaseutuyhteiskunnan sosiaalista rakennetta (esim. Arensberg-Kimball 1948, Williams 1956 ja 1963), ja joissa siirtymistapahtumaan on kiinnitetty enemmän tai vähemmän huomiota, on erityisesti mainittava Williamsin 1963 Länsi-Englannissa tekemä tutkimus. Se perustuu tietoihin, jotka tutkija on kerännyt paikanpäällä suoritettujen haastattelujen avulla ja erilaisista arkistolähteistä. Tutkimuksessa esitetään runsaasti näkökohtia ja mielipiteitä.

\section{Aiheet}

Ilmiöistä, joihin sukupolven vaihtumista käsittelevät tutkimukset kohdistuvat, mainittakoon erityisesti siirtymisajankohdan riippuvuus nuoren ja vanhan isännän iästä, mutta myös siirtymismuoto ts. siirtyykö tila perintönä, lahjana vai kaupan tms. muodossa vanhemmilta. Useissa eri puolilla Eurooppaa suoritetuissa tutkimuksissa on osoitettu, että tilan luovutus nuoremmille tapahtuu myöhemmin kuin ennen. Paitsi niitä taloudellisia haittoja, jotka välillisesti ovat maatilatalouden ukottumisilmiön seurauksia, liittyy myöhäiseen siirtymiseen muitakin ongelmia. Eräissä tutkimuksissa on huomattu, että tilan siirtymisellä ja naimisiinmenohetkellä on tietty yhteys (Binder 1953, Sundby 1955, William 1956 ym.). Jos tilan luovuttaminen viivästyy, voi se siten vaikuttaa perheenmuodostukseen epäsuotuisasti. Se voi lisäksi aiheuttaa kitkaa ja jännitystä nuoremman ja vanhemman sukupolven välillä, vähentää nuoren sukupolven työhalua, lamauttaa aloitekykyä jne. varsinkin silloin kun on epäselvää kuka lapsista tulee perimään tilan (Planck 1964, Williams 1963).

Myös siihen seikkaan, tapahtuuko tilan siirtyminen vanhempien vielä ollessa elossa vai heidän kuolemansa jälkeen, on kiinnitetty paljon huomiota. Tässä suhteessa tavat näyttävät vaihtelevan eri seuduilla. Usein'korostetaan joko suoraan tai epäsuorasti, että siirtyminen on edullista 
silloin kun vanhemmat ovat vielä elossa. Tällöin vältytään tilan osittamisesta, mahdollisista erimielisyyksistä perinnönjaossa jne. Samalla voidaan järjestää eläkeasiat, jotka varsinkin eloon jääneen puolison kannalta voivat olla tärkeitä. Tilan siirtyminen vanhemmalta sukupolvelta nuoremmalle tapahtuu tällöin eri tavalla riippuen maan tavoista, esim. kaupan tai vastaavanlaisen sopimuksen muodossa. Eräs muoto, joka on melko yleinen Yhdysvalloissa, on isän ja pojan välinen tilan hallintaa koskeva sopimus.

Monet tutkijat ovat myös olleet kiinnostuneita selvittämään, onko joku lapsista syntymäjärjestyksen perusteella etuoikeutettu perijä. Useat tutkimukset osoittavat, että paikoittain vielä pidetään kiinni vanhimman lapsen tai, kuten esim. eräillä seuduilla Saksassa, nuorimman lapsen etuoikeudesta (Reichle 1964, Trotha 1958). Perinteisiin nojautuva etuoikeus näyttää kuitenkin kaikkialla vähitellen häviävän.

Muista suhteellisen paljon tutkituista ilmiöistä mainittakoon eläkejärjestelmä (Eisenkrämer 1960, Galloway 1955, Hornslien 1957, Lichterman 1957 ym.). Omassa maassamme on sama aihe ollut tarkastelun kohteena muutamissa tutkimuksissa (Högnäs 1935, Koskikallio 1927, Kivialho 1927). Viimeksi mainituissa tutkimuksissa valotetaan eläkejärjestelmää muutaman kihlakunnan käsittävillä alueilla Pohjanmaalla, Hämeessä ja Turunmaassa 1800 luvulla ja 1900-luvun alussa. Sekä vanhemmissa että nuoremmissa tutkimuksissa selvitetään eläkkeen rakennetta ja arvoa. Maatalouden eläkejärjestelmä muodostaa joustavan menetelmän suorittaa maksu kiinteistöstä vähitellen vuosien mittaan. Haittapuolena mainitaan $\mathrm{mm}$. se, että eläkkeen suorittaminen voi muodostua epävarmuutta aiheuttavaksi tekijäksi, koska ei tiedetä kuinka kauan eläkettä joudutaan suorittamaan.

Edelleen on tutkimuskohteina ollut väistyvien perinnönsaajien ts. kotitilan jättävien lasten kohtalo (Bendel 1959, Trotha 1958). Tähän liittyvä ongelmapiiri on ehkä erityisesti Saksalle ominainen. Siellä voidaan tila kokonaisuudessaan siirtää yhdelle perijälle, jolloin väistyvät perijät joutuvat tilalle jääneen perijän suhteen huonompaan asemaan. Väistyviin perijöihin kohdistuvat tutkimukset selvittävät, mitä heille suoritetaan perintönä, mihin ammatteihin he siirtyvät, heidän sosiaalinen asemansa jne. Väistyvien perijöiden ongelma liittyy kiinteästi maatilan jatkuvuuteen vaikuttaviin tekijöihin. Jos he syystä tai toisesta eivät ole hankkineet muuta ammattia ovat mahdollisuudet perintönä saadun maatilan jakamiseen suuremmat kuin jos heillä on oma ammatti.

Useat maatilan siirtymiseen kohdistuvat tutkimukset käsittelevät tätä tapahtumaa enemmän tai vähemmän sosiologisena ilmiönä. Mutta inhimillisten ja sosiaalisten ongelmien ohella kytkeytyy luonnolliseen sukupolven vaihtumiseen puhtaasti taloudellisia kysymyksiä. Harvat tutkijat ovat kuitenkaan lähestyneet ongelmaa maatalousekonomisteina.

Niissä tutkimuksissa, joissa tilan siirtymistä tutkitaan taloudellisena ilmiönä, pyritään mittaamaan kuinka suuri on tilalle jääneen viljelijän rasitus, kun hänen täytyy lunastaa kanssaperijöiden osuuksia tai suorittaa eläkettä vanhemmilleen. Taloudellista rasitusta on silloin verrattu tilan suuruuteen tai tuottoarvoon (Eisenkrämer 1960, Trotha 1958). Tähän liittyvät kysymykset ovat kuitenkin arkaluontoisia ja vaikeasti tutkittavissa, joten tämä ongelma usein jää selvittämättä. Kuitenkin se on tutkimisen arvoinen. Muun muassa maatalouspolitiikan kannalta on tärkeätä tietää, kuinka paljon tilan haltuun ottaminen tulee maksamaan tilan uudelle viljelijälle, kuinka paljon sukupolven vaihtuminen maksaa uudelle viljelijäpolvelle ja maatilataloudelle. Sukupolven vaihtumisen yhteydessä virtaa pääomaa pois maataloudesta perijöiden lunastusosuuksina. Tämä pääoman siirto maatilataloudesta tapahtuu muihin elinkeinoihin ja niistä toimeentulonsa ansaitsevan väestön hyväksi. Sisäisen muuttoliikkeen seurauksena se onkin nykyaikana aivan toista luokkaa kuin muutama vuosikymmen sitten. Pitkällä tähtäyksellä tuottavampiin elinkeinoihin tapahtuva pääomansiirto saattaa hyödyttää yhteiskunnan taloudellista kasvua enemmän kuin jos siirtoa ei olisi 
tapahtunut. Samalla se kuitenkin hidastuttaa ja vaikeuttaa pääomayritykseksi muuttuvan maatalouden kehitystä suhteessa muihin elinkeinoihin. Koska tämäntapainen kehitys ei ole yhteiskunnan etujen mukaista, joudutaan maataloudesta pois virrannutta pääomaa jollakin tavalla kuitenkin johtamaan takaisin maatalouteen.

Sukupolven vaihtumista selvittäviä tutkimuksia on pääasiassa tehty niissä maissa, missä yleensä ollaan kiinnostuneita maaseudun ongelmista, missä maaseudun kasvot muuttuvat tai missä maaseutusosiologialla jo on varma sija. Tämän tapaisia tutkimuksia ei liene suoritettu kehitysmaissa eikä yleensä niissä maissa, joissa kaupungistuminen ja teollistuminen on vasta alussa. Tutkimusten kohteena ovat yleensä olleet vain pienet alueet. Kun vielä otetaan huomioon se, että siirtymismuodot ja niihin kytkeytyvät tavat vaihtelevat seudulta toiselle, jopa kylästä kylään, on vaikea sanoa missä määrin tällaiset tutkimukset ovat edustavia, kun on kyseessä maakunta tai koko maa. Ne ovat siten ehkä pääasiassa suuntaa antavia tutkimusmenetelmien samoin kuin tulostenkin kannalta. Ne antavat tietoja muutosprosessin kulusta ja vaikutuksista kaupungistuvassa maaseutuyhteiskunnassa, mutta ovat useimmiten maantieteellisesti liian suppeita jotta ne muodostaisivat pohjan suunnitelmalliselle maatalous- ja yhteiskuntapolitiikalle.

\section{Kirjallisuus}

Ahrensberg, C. M. - Kimball, S. T., Family and Community in Ireland. Cambridge, Mass. 1948.

Bendel, Bernold, Das Problem der weichenden Erben im Anerbenrecht. Berlin 1959.

Binder, $F$., Die Besonderheiten der Hofübergabe und die Nachwuchslage in den Landwirtschaftsbetrieben des Landkreises Memmingen. Diss. Hohenheim 1953.

O'Byrne, John J. H. - Timmons, F., Farm Property Transfers. Iowa State College Bull. P125, Iowa 1959.

Dierks, W., Herkunft und Begrundung unterschiedliche Vererbungsgewohnheiten bei bäuerlichen Anwesen auf dem Schwarzwald, in der Rheinebene und der Vorbergzone. Diss. Freiburg 1954.

Eisenkrämer, K., Das Altenteil in der westdeutschen Landwirtschaft und seine betriebswirtschaftliche Problematik. Berichte über Landwirtschaft 1960, 1.

Galloway, Robert R., Farmers' Plans for Economic Security in Old Age. Kentucky Agr. Exp. St. Bull. 626. Lexington 1955.

Högnäs, Hugo, Sytning och arvslösen i den folkliga sedvänjan uti Pedersöre och Nykarlebybygden $1880-1914$. Turku 1938.

Hornslien, John, Generasionsskifte på gårdsbruk i 3 herred på Vestlandet. Tidskrift for det norske landbruk 1957, 8-9.

Kivialho, K., Maatalouskiinteistöjen omistajanvaihdokset ja hinnanmuodostus Halikon tuomiokunnassa 1851-1910. Helsinki 1927.

Koskikallio, Onni, Maatalouskiinteistöjen eläkerasituksesta Pirkkalan ja Ruoveden kihlakunnassa vuosina 1800-1913. Suomen Maataloustieteellisen Seuran julkaisuja 1927, 12.

Lichtermann, L., Die Altenteile südniedersächsischer Hofübergäber. Berichte über Landwirtschaft 1957, 4.

Parsons, Kenneth H. - Waples, Eliot O., Keeping the Farm in the Family, Univ. of Wisconsin, Research Bull. 159. Madison 1945.

Pipping, Knut, Generationsväxlingen inom jordbruket. Tidskrift för lantmän och andelsfolk 1961, 21.

Planck, Ulrich, Der bäuerliche Familienbetrieb zwisehen Patriarchat und Partnerschaft. Stuttgart 1964. 
Post, J. H. - Jacobs, A. J., Generatie- landwirtschaftlichen Grundeigentums in wisseling in de Landbouw, LandbouwEconomisch Instituut, Studies 7. s'Gravenhage 1963 .

Reichle, R., Die Auswirkung der güterrechtlichen Gebräuche und die Erbgewohnheiten auf Hofübergabe im Würtenbergischen Algau. Diss. Stuttgart-Hohenheim 1953.

Röhm, Helmuth, Handhabung und Auswirkung der Hofübergabe in Südwestdeutschland. Bielefeld-Bethel 1955.

Röhm, Helmuth, Die Vererbung des Baden-Württenberg. Remagen 1957.

Sundby, C., Ökonomiske problemer ved generasionsskifte på gårdarne. Norges landbrukshöjskole. (Moniste). 1955.

Trotha, Wilhelm $v$., Der gegenwärtige Stand der Erbverhältnisse in der oberfränkischen Landwirtschaft. Bayerische landwirtschaftliche Jahrbuch. 1958, 1. Williams, W. M., The Sociology of an English Village: Gosforth. London 1956. Williams, W. M., A West Country Village: Ashworthy. London 1963. 